\title{
Research and Design of Hotel Management System Model
}

\author{
Jingda Yang \\ Jilin Business and Technology College, Changchun, 130062, China \\ Email: yjdsw@126.com
}

Keywords: Hotel Management; System Modeling; Demand Analysis; Database; Design.

\begin{abstract}
In order to make the hotel management work systematic, standardization and automation, achieve the aim of improving the efficiency of hotel guest room management. This paper designs the hotel management system, the overall mission of system development is to make the office staff can quickly and easily complete the hotel guest room management task. From the Angle of actual application to system illustrate the basic situation; And then introduced the system analysis and modeling, focusing on the functional requirements of the hotel management system was analyzed, at the same time on the system design goal, the system use case diagram and so on several aspects, Hotel management system is mainly introduced the three layers of frame structure, and the database design, etc. Application of this system can be flexibly and conveniently on the computer management hotel rooms, thus greatly improves the processing speed, make the management more modern.
\end{abstract}

\section{Introduction}

Hotel industry is facing the increasingly fierce competitive environment, on the one hand, the traditional hotel industry is difficult to get rid of low prices, low occupancy rate and low profit "three low" strange circle; Study hotel management in the information service, room information query, booking and management functions, for business processes effective integration of hotel management, complete information sharing in the process of management, to provide customers with convenient and efficient hotel service. Through this system can be in the hotel customers, service personnel, managers and owners to bridge the interconnection, the full application of information management technology, combined with the actual business, improving hotel service quality, standardized service standards.

\section{The Requirements Analysis of System Functional}

Hotel management system is mainly used in the hotel daily information set, entry and query, at the same time in between customers, waiter, administrators, owners set up an interactive platform for the visit [1]. In terms of data query, for system administrators, who will take care of the hotel guest room information, passenger occupancy, statistics and analysis for all kinds of other information to customize the query, to complete the manual monitoring functions of the database data [2]. In terms of database maintenance, meet the demand of system administrators to database daily management, mainly to the local database system for management and custom, including the management of the data table, guest room data change, passenger check-in information input and rate data calculation, etc [3].

The Customer Information Management Needs. Customer information management is through the in-depth analysis of customer information, to improve customer satisfaction, so as to enhance the enterprise the competitive ability. Goal is to reduce sales cycle and cost of sales, increase their income, seeking to expand business for new markets and channels, and improve customer value, satisfaction, profitability and loyalty.

The Hotel Information Management Needs. The hotel information management includes the following functional requirements, such as personnel information related to maintenance, counter management, building management and business information management and analysis, etc [4]. 


\section{System Use Case Model}

Use Case Diagram is widely applied in all kinds of system development is the first step in the software requirements analysis. It tells you how to use a system, which is how to understand the system in some functional purposes. Use case diagram shows the relationship between users and system requires the user to provide what kind of service, and user need to provide what kind of service system.

System Overall Use-case Diagram. Background management subsystem and Customer service subsystem is display system which is divided into two subsystems, Customer and server through the system activity and generate data, managers can through this system to manage data between the client and waiter, as shown in Figure 1.

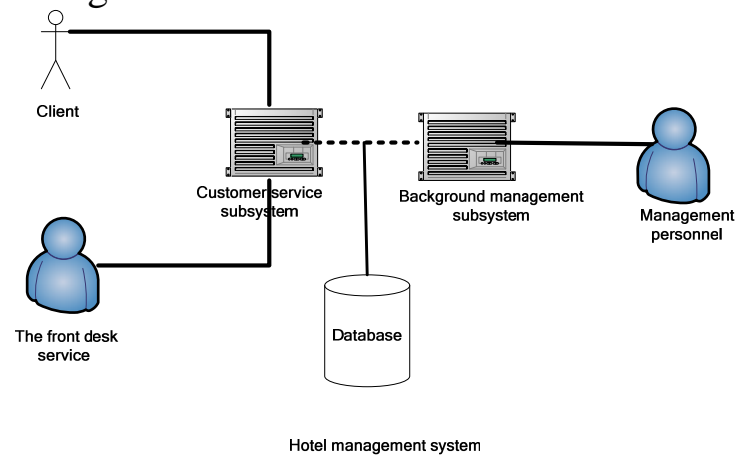

Fig.1. System use case UML diagram

Customer Service Subsystem Use Case Diagrams. This use case diagrams mean, when a customer has order, consultation, checkout as needed by the corresponding service calls, and told the waiter your accordingly demand. Waiter first on the computer operating system to the customer requirements in terms of registration, and then according to the telephone number information for clients homes, and update the management customer information , finally placing order for this service. Managers can also use this system to the above between the customer and waitress what happened manage service activity [5], as shown in Figure 2.

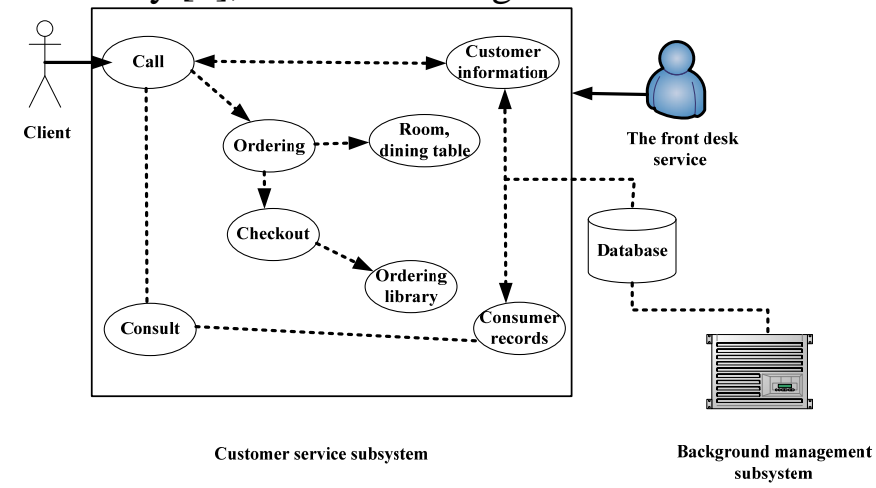

Fig.2. Customer service subsystem use case diagram

Use Case Diagram of Background Management Subsystem. This use case diagram means, through the system management function, the administrator to the customer of consumption record, the customer details, room number, floor number, dining tables/seats, manage business analysis function and so on, as shown in Figure 3.

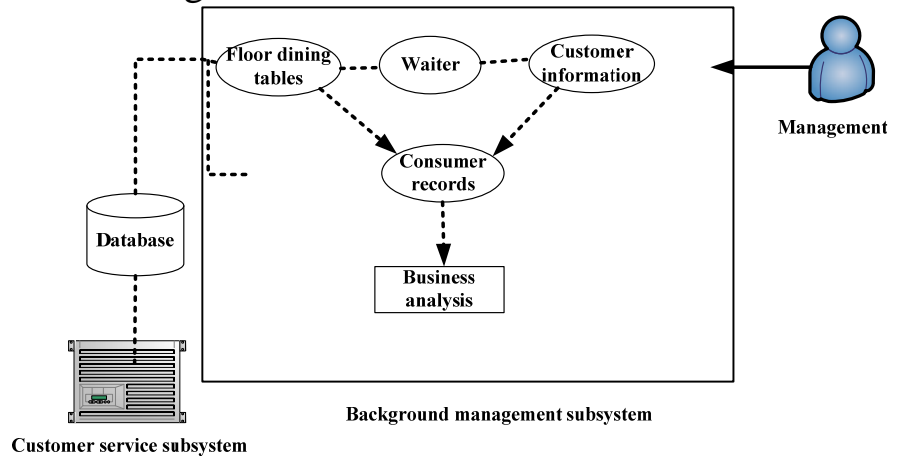


Fig.3. Use case diagram of customer management subsystem

\section{System Overall frame Design}

Hotel management information system adopts three layers of system design; it deals with in the middle tier of business rules, data access, and the check of legitimacy [5]. This system use the Microsoft DNA structure, the definition of three layers respectively is: the presentation layer, the business logic layer and data access.

The system users are mainly including system administrators, foreman users and waiter. Among them: the system when initialization default "Admin" system administrator user, in the program design is added to the database. The Admin user has to create users, delete users, and modify user information system such as all the other functions. Foreman users can manage the server user, including the creation of the user, modify the user information, and delete user information, etc. But he cannot manage other foreman users. Foreman users can use in addition to the statistics of all the other functions. Ordinary user permissions are low; he can only manage user information. Ordinary users can only access the receptionists and front desk cashier function of two modules, as shown in Figure 4.

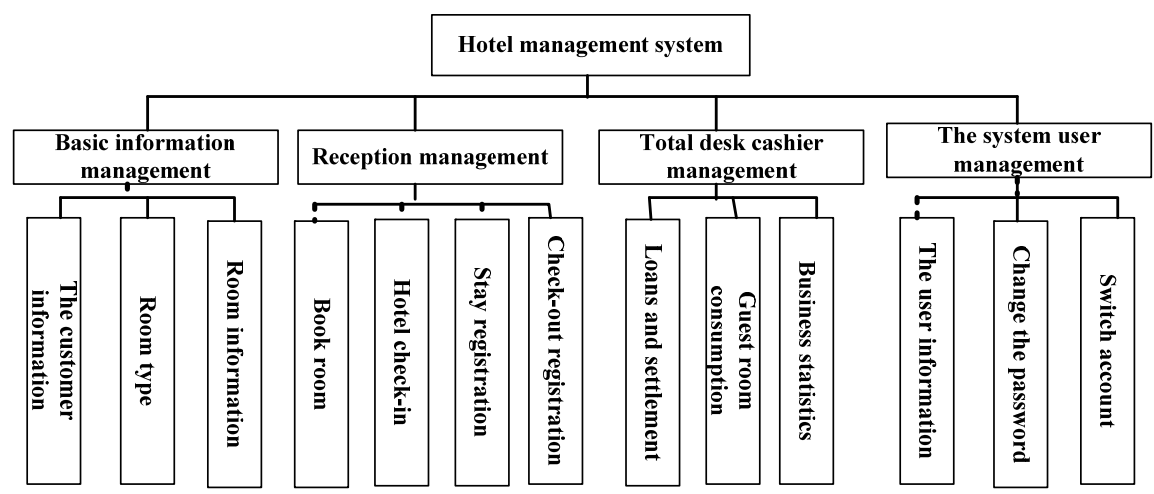

Fig.4. System function module diagram

\section{The Design of the Database}

In the hotel management system, database design work mainly includes the database management system, needed to create tables, can also design related views and stored procedures. All the design work is in SQL Server 2008 environment operation and implementation [6].Database Hotel contains the following seven tables: UsersInfo, CustomersInfo, RoomCategory, Roominfo,RoomStatus, RoomOperation , History,

The User Information Table. User information table (UsersInfo) used to store the system user basic information, the table UsersInfo structure as shown in table 1.

Table 1. user information table (UsersInfo)

\begin{tabular}{|c|c|c|}
\hline $\begin{array}{l}\text { Num } \\
\text { ber }\end{array}$ & $\begin{array}{l}\text { Field } \\
\text { Name }\end{array}$ & $\begin{array}{c}\text { Data } \\
\text { structure }\end{array}$ \\
\hline 1 & UserId & Int \\
\hline 2 & Name & 0) $\begin{array}{r}\text { Varchar(5 } \\
\end{array}$ \\
\hline 3 & $\begin{array}{l}\text { Passwor } \\
\text { d }\end{array}$ & 0) $\operatorname{Varchar(5}$ \\
\hline 4 & Gender & Int \\
\hline 5 & Email & 0) $\quad \begin{array}{l}\text { Varchar(5 } \\
\end{array}$ \\
\hline 6 & Address & 0) $\begin{array}{l}\text { Varchar(5 } \\
\end{array}$ \\
\hline 7 & Telepho & Varchar(5 \\
\hline
\end{tabular}




\begin{tabular}{|c|l|l|}
\hline & ne & $0)$ \\
\hline 8 & $\begin{array}{l}\text { Departm } \\
\text { ent }\end{array}$ & \multicolumn{1}{|c|}{ Varchar(5 } \\
\hline 9 & \multicolumn{1}{|c|}{ Type } & \multicolumn{1}{|c|}{ Int } \\
\hline
\end{tabular}

The Customer Information Table. Customer information table (CustomersInfo) is used to store the basic information of the hotel customers, table CustomersInfo structure as shown in table 2.

Table 2. the customer information table (CustomersInfo)

\begin{tabular}{|c|c|c|}
\hline $\begin{array}{c}\text { Num } \\
\text { ber }\end{array}$ & $\begin{array}{c}\text { Field } \\
\text { Name }\end{array}$ & $\begin{array}{c}\text { Data } \\
\text { structure }\end{array}$ \\
\hline 1 & $\begin{array}{c}\text { CIdentit } \\
\text { yId }\end{array}$ & $\begin{array}{c}\text { nVarchar( } \\
50)\end{array}$ \\
\hline 2 & CName & $\begin{array}{c}\text { nVarchar( } \\
50)\end{array}$ \\
\hline 3 & CPhone & $\begin{array}{c}\text { nVarchar( } \\
50)\end{array}$ \\
\hline
\end{tabular}

Guest Room Types Table. Room type table (RoomCategory) is used to store the basic information of the hotel all the room types, table RoomCategory structure as shown in table 3.

Table 3.Guest room types table

\begin{tabular}{|c|c|c|}
\hline $\begin{array}{c}\text { Num } \\
\text { ber }\end{array}$ & $\begin{array}{c}\text { Field } \\
\text { Name }\end{array}$ & $\begin{array}{c}\text { Data } \\
\text { structure }\end{array}$ \\
\hline 1 & $\begin{array}{c}\text { RCategor } \\
\text { yId }\end{array}$ & Int \\
\hline 2 & Name & Varchar(5 \\
& 0) \\
\hline 3 & Area & Float \\
\hline 4 & BedNum & Int \\
\hline 5 & Price & Money \\
\hline 6 & $\begin{array}{c}\text { AirCondit } \\
\text { ion }\end{array}$ & Int \\
\hline 7 & TV & Int \\
\hline
\end{tabular}

Guest Room Information Table. Guest room information table (RoomsInfo) is used to store the hotel guest room information, table RoomsInfo structure as shown in table 4.

Table 4, guest room information

\begin{tabular}{|c|c|c|}
\hline $\begin{array}{l}\text { Num } \\
\text { ber }\end{array}$ & $\begin{array}{l}\text { Field } \\
\text { Name }\end{array}$ & $\begin{array}{c}\text { Data } \\
\text { structure }\end{array}$ \\
\hline 1 & RoomId & Int \\
\hline 2 & $\begin{array}{l}\text { RCategor } \\
\text { yId }\end{array}$ & Int \\
\hline 3 & $\begin{array}{ll} & \text { RPostitio } \\
\mathrm{n} & \\
\end{array}$ & $\begin{array}{l}\text { nVarchar( } \\
\text { 50) }\end{array}$ \\
\hline 4 & $\begin{array}{l}\text { Descripti } \\
\text { on }\end{array}$ & $\begin{array}{l}\text { nVarchar( } \\
50)\end{array}$ \\
\hline
\end{tabular}

\section{Conclusions}

In this paper, the system overall design was described; the system framework design part of the system uses a three-tier architecture analysis and elaboration. In the introduction to the design of the database, the system involved in the main table structure and storage processes were introduced. The hotel management system mainly to various internal management of the hotel automation, computerization and information technology, improve the hotel each department, all kinds of personnel office efficiency, to provide customers with high quality hotel services. 


\section{References}

[1] Xu Wenyuan, He Xianghui: "Hotel lobby management practices",Guangdong Economic Press, 2005.10

[2] He Xianghui, "the hotel lobby Management Practice (third edition), Guangdong Economic Press Limited, 2011.09

[3] Dong Hongchun. "Star hotel desk manager safety management manual" ,Chemical industry press, 2010.01

[4] Peng Weimin. hotel management system based on the needs of the Modeling and Implementation .management information systems, 2000.9

[5] JiGenBao, editor chief .the hotel management practices ,Tsinghua university press, 2011.08

[6] Chen Yueguo, Wangjing Chun data integration overview ,Computer Science, 2004 (5) 